\title{
ACADEMIC LIBRARIES
}

\section{Barbara I. Dewey \\ 1. INTRODUCTION}

Academic libraries in North America support institutions of higher education in the United States and Canada, both private and public in nature. They comprise an integral and important part of creating, preserving, and accessing the world's knowledge. This chapter will describe academic libraries as they transform to meet the needs of $21^{\text {st }}$ century students, scholars, and the many communities they serve. Understanding academic libraries also requires a basic knowledge of the higher education environment in North America and how it has emerged. Important aspects of today's libraries will be explored in terms of teaching and learning, research, and scholarly communication. Other important aspects include digital initiatives, technical services, public services, professional preparation, and a summary of important issues facing academic libraries today as they strive to advance knowledge generally and in their specific institutions.

\section{ACADEMIC LIBRARIES: TRANSFORMATION AND CHANGE}

Academic libraries are in a state of major change and transformation moving from a just in case model anticipating student and faculty needs through largely print resources to a just in time digital content and delivery service model. "In the transitional or responsive academic library, the processes of information acquisition, synthesis, navigation, and archiving are increasingly focused on networked and interactive access to digital multimedia ... at point of need, and on the innovative application of electronic technologies, according to Neal. ${ }^{1}$ Academic libraries are both archive and dynamic learning and information-creation environments fueled by ever changing technology. All aspects of the academic library are affected by this transformation.

\subsection{The Higher Education Environment}

What is meant by higher education? In North America it generally means research universities, four-year colleges, two-year community colleges and technical schools. Transformation is also occurring in colleges and universities in an environment of inherent conservatism combined with cutting edge discover and creative achievement. This dichotomy is not unlike the tensions felt in academic librar-

Neal, James G. "The Entrepreneurial Imperative: Advancing from Incremental to Radical Change in the Academic Library." portal: Libraries and the Academy, Vol. 1, No. 1 (2001), pp. 1-13. 
ies in the early part of the $21^{\text {st }}$ century. Libraries built on centuries of largely Western European intellectual development must now embrace different models of operation, collection building, ownership, and access.

North American institutions of higher education emerged built on European developments specifically from the earliest Western universities in Paris and Bologna beginning in the $12^{\text {th }}$ century. The curriculum was based on seven liberal arts seen as the foundation of education - mathematics, astronomy, geometry, music, grammar, rhetoric, and logic. Professional areas such as law, medicine, and theology also emerged. Library catalogues were created, first in the Sorbonne, boosted by the advent of printing and growth in book production. Comprehensive research universities were modeled out of Germany but took on a strong individual freedom of inquiry model in North America.

The first university in North America is considered to be the University of Santiago in the Dominican Republic. Harvard University is the first university established in the United States followed by the College of William and Mary. The first public university was the University of Georgia opening in 1795. Libraries begun to appear, often started from collections of individual faculty members. In the $20^{\text {th }}$ century the emphasis on research as well as teaching increased the number of journals and books published. ${ }^{2}$ Professionalization of the disciplines including librarianship and the emergence of many learned societies (who also published journals) also increased the depth and size of library collections in academic institutions. Frequent funding crises and explosion of information technology fueled major changes that are accelerating today.

Academic libraries exist within their parent institutions' context. They confront major issues of funding, accountability, recruitment of the best and brightest, competition for research and private dollars, increased emphasis on diversity and internationalization, and a more user centered, diffuse approach fueled by innovative technologies supporting non-traditional learning, teaching, communication, and scholarship creation. Major philosophies of higher education including academic freedom, relative independence of faculty, loathing of corporate models and bureaucracy, the high value placed on cutting edge discovery coupled with higher education's conservative view of change, and ultimately the dedication to preparing young people for life's challenges inform the academic library's overall mission and strategic priorities.

Library deans and directors in academic libraries must identify and communicate effectively with key campus players including academic administrators (Provost, Chancellor, President, Deans, and department heads) and other administrators (Chief Information Officer, Chief Financial Officer, administrators for space, human resources, general counsel, etc.). Additionally key players in the library, it-

2 Budd, John. (1998). The Academic Library: Its Context, Its Purpose, and Its Operation. Englewood, Colorado: Libraries Unlimited. 
self, include the library administrative team, department heads, librarians, other library professionals, staff, and student library assistants. Student and faculty constituencies are also critically important contacts.

Campus organizations must also be engaged by the library including the Faculty Senate, Deans Council, Library advisory committees, Student Senate, representative unions, student services, campus staff committees, and Library Friends groups. Librarians in successful North American academic libraries are at the table when important campus initiatives are pursued or should be. Examples are strategic planning, curriculum revision, efforts towards student and faculty recruitment, improving quality and ranking of programs, and the like.

\section{TEACHING AND LEARNING}

Academic librarians are increasing their focus on support of teaching and learning. Specifically, they see as crucial their role in lifelong student success for critical thinking and the ability to find and assess information as needed in the classroom and beyond. Major national initiatives to support these efforts include the American College and Research Libraries' (ACRL) information literacy initiatives, specifically the Information Literacy Competency Standards for Higher Education. ${ }^{3}$ The Canadian Library Association sponsors the Information Literacy Interest Group with accompanying resources and activities. ${ }^{4}$

Given the major investment academic libraries make in providing extensive collections and access to many general and discipline-related databases, large collections of full text electronic journals, and legacy print collections, librarians are motivated to push for the use of these collections in student learning and research. This push is particular strong given the propensity for students to go directly to search engines, especially Google, exclusively for their research and information needs. Academic librarians and faculty throughout the institutions are challenged to work together to come up with strategies ensuring that students learn, at some level, comprehensive research skills, gaining an appreciation of scholarship in their chosen field regardless of where the student begins their research. The habits of students to ignore library websites and collections are well documented in the OCLC study, College Students' Perceptions of Libraries and Information Resources. ${ }^{5}$ Academic librarians, in partnership with faculty, are developing a variety of strategies to imbed information literacy and critical thinking skills throughout

3 ACRL Information Literacy Initiatives, http://www.ala.org/ala/acrl/acrlissues/acrlinfolit/information literacy.cfm

4 Canadian Library Association. Information Literacy Group. http://cybrary.uwinnipeg.ca/ilig/

5 OCLC. College Students Perceptions of Libraries and Information Resources. http://www.oclc.org/ reports/perceptionscollege.htm 
the curriculum. These include tutorials, Web components, peer advisor programs, course/subject guides, and comprehensive strategies for required courses and/or general education offerings.

Recent advances in teaching and learning include user-centered strategies focused on current generational characteristics of students and results of library assessment studies. These include development of technology-intensive shared spaces or learning commons which provide a variety of related services including library research support, information technology services, tutorial assistance, spaces for group/individual study, presentation spaces, social spaces, and the like. All of these functions are increasingly housed in attractive and widely accessible library spaces, which once featured legacy print collections no longer needed in our digital environment.

\section{PUBLIC SERVICES}

Public services in North American academic libraries traditionally have centered on reference librarians' work. Reference librarians still, in most academic libraries, work one-on-one with students and faculty pursuing information queries, assignments, and research. Additionally, they teach and develop subject-based tools and services. However, the Web has certainly changed the face of reference and public services in profound ways requiring that academic librarians develop new methods of publicizing their services and reaching their clientele including through virtual means. Information-seeking behavior increasingly depends on an individual's use of search engines independent of the library. However, the academic library and its public service librarians, regardless of what they are called, continue to play a critical role in developing the social, culture, and intellectual environment that is the North American research library. Students remain largely residential and do congregate in their institution's library to study, socialize, and attend events. Public service librarians including reference, access services, bibliographers, and digital media experts continue to provide the human touch for students who wish to be around others while studying. However, they are also providing this "touch" through innovative virtual services. These services compete with similar services such as Ask.Com ${ }^{6}$ so they must be seen as effective and relevant to students. They must be "pushed" to students through a variety of means since students do not initially start with the library or its website.

Many North American academic libraries serve graduate students and all serve faculty. These constituents need different kinds of support from the library. They are involved in long-term and complex research agendas involving the need for

6 Ask. Www.ask.com 
specific resources and the most up-to-date data and publications. They are asking for and getting specific types of spaces for quiet and contemplative study away from the lively information commons-type spaces. The term "research commons" is beginning to take hold to describe these kinds of spaces, some of which are virtual.

Large universities in North America still feature library systems that include branch or subject-based libraries. Given the increasing interdisciplinary nature of scholarship, the increased body of digital resources, and the competition for space campus-wide discussion of consolidation is becoming more common. On the other hand there is a movement to place librarians with subject expertise closer to their constituents or as part of research teams, centers, or other disciplinary initiatives.

\section{SCHOLARLY COMMUNICATION, RESEARCH, AND COLLECTION MANAGEMENT}

Faculty who make up North American colleges and universities are the primary creators of scholarship. The academic library role in the scholarship communication has evolved to one of advocacy for broad access and dissemination of scholarship. Institutes of higher education are in the strange position of paying faculty, in part, to create scholarship and then paying commercial and society publishers to obtain that scholarship. Over the past few years active national efforts, some spanning both the US and Canada higher education environments, have emerged to support the open access movement. In particular the Association for Research Libraries (ARL) launched the Create Change initiative to help administrators, faculty, and librarians understand and take appropriate action to remove barriers of access to scholarship. ${ }^{7}$ The Canadian Association of Research Libraries (CARL) also has initiated specific actions to improve access to research in Canada. ${ }^{8}$ Scholarly Publishing and Academic Resources Coalition (SPARC) is an alliance of universities, research libraries, and organizations dedicated to open access and has been successful in a number of arenas to advance new forms of digital scholarly publishing and communication. ${ }^{9}$

\subsection{Institutional Repositories}

Scholarly communication initiatives also include advocacy for setting up institutional and/or disciplinary repositories where an institution's scholarly output can be accessed by all. According to Lynch, "a university-based institutional reposi-

\footnotetext{
Association of Research Libraries. Create Change. http://www.createchange.org/

8 Canadian Association of Research Libraries. Scholarly Communication. http://www.carl-abrc.ca/ projects/scholarly_communication/scholarly_communication-e.html

Scholarly Publishing and Academic Resources Coalition. http://www.arl.org/sparc/
} 
tory is a set of services that a university offers to the members of its community for the management and dissemination of digital materials created by the institution and its community members." ${ }^{, 10}$ Institutional or digital repositories include, but are not limited to electronic theses and dissertations, faculty publications, university archival materials, conference proceedings, video of important university events, and digital material in any other form important to the output of the university. Examples include MIT's DSpace, ${ }^{11}$ Ohio State's Knowledge Bank, ${ }^{12}$ and Queen's University's QSpace. ${ }^{13}$

\subsection{Copyright Education}

Copyright education and application is another area of activity for North American academic libraries. ARL and CARL have worked on helpful tools for faculty to guide them in negotiating rights to their publications to ensure open access and the ability to deposit their work locally. Additionally, academic librarians are involved in ensuring appropriate application of fair use elements of copyright laws for educational purposes. Advocacy at the national level to monitor copyright legislation is a continuing and important activity. Resources related to copyright are found on both the $\mathrm{ARL}^{14}$ and $\mathrm{CARL}^{15}$ websites.

\subsection{Digital Initiatives}

If it is online it does not exist and thus, digital initiatives form the key foundation for advances in open access and scholarly communication. Scholars and librarians are hearing this sentiment from students but also from each other. The imperative to build digital collections and services is paramount for academic libraries in North American. Major initiatives are underway to, not only digitize unique collections and make them widely available, but to also digitize legacy print collections. Key players and programs in this arena include the Digital Library Federation, ${ }^{16}$ Library of Congress American Memory Project, ${ }^{17}$ Library Archives Canada, ${ }^{18}$ Google Books Library Project, ${ }^{19}$ Open Content Alliance, ${ }^{20}$ and projects

${ }^{10}$ Clifford A. Lynch, "Institutional Repositories: Essential Infrastructure for Scholarship in the Digital Age,” ARL Bimonthly Report 226 (February 2003), 1-7. Online at http://www.arl.org/newsltr/226/ ir.html

11 DSpace at MIT. http://dspace.mit.edu/

12 The Knowledge Bank at Ohio State. https://kb.osu.edu/dspace/index.jsp

13 QSpace at Queen's University. https://qspace.library.queensu.ca/

14 ARL (2007). Know Your Copy Rights: Using Copyrighted Works in Academic Settings. http:// www.knowyourcopyrights.org/index.shtml

15 CARL. Copyright. http://www.carl-abrc.ca/projects/copyright/copyright-e.html

16 Digital Library Federation (DLF). http://www.diglib.org/

17 Library of Congress American Memory Project. http://memory.loc.gov/ammem/index.html

18 Library Archives Canada. http://amicus.collectionscanada.ca/electroniccollection-bin/Main/Adv Search?coll $=11 \& \mathrm{l}=0 \& \mathrm{v}=1$

19 Google Books Library Project. http://books.google.com/googlebooks/library.html

${ }^{20}$ Open Content Alliance. http://www.opencontentalliance.org/ 
throughout North American academic libraries digitizing individual collections, especially manuscript and special collections. These efforts have the potential of changing the face of academic libraries in terms of collection, space, and service priorities.

Building the virtual academic library includes a heavy emphasis on services. If students and faculty are coming into the library from a virtual portal or gateway then academic libraries must provide services in the virtual sense. Initially these included email reference, ability to reserve or renew books, and the ability to manage citations. These services have broadened to include social networking and interactive capability such as instant messaging and chat services, tools available on the library website to help students and faculty manage scholarly resources in a variety of ways to support their teaching, learning, and research. Imbedding library resources, tools, and virtual assistance directly into course management systems such as Blackboard are common in today's academic library. Application of social networking technologies is underway through academic libraries' presence on sites such as Facebook and the creation of Blogs.

More global efforts to expand the virtual library and bring in to the forefront include OCLC WorldCat, ${ }^{21}$ DLF's Acquifer Project, ${ }^{22}$ and many other partnership projects to bring together formerly disparate research collections by subject. Canadian research libraries especially have made strategic progress on digitizing Canadian culture and heritage in a comprehensive way. Commercial publishers are adding to available digital content, not only in sciences and technology, but in large reformatting projects converting microfilm sets to full text digital content. Consortia of libraries throughout North America are engaged in collaborative digitization projects. Funding sources for these projects include foundations and federal grant programs.

Academic libraries in North America are beginning to work in partnership with other key players to develop cyber infrastructures for sciences, social sciences, and humanities scholarship and datasets. These efforts are still emerging but will provide access to and sustained support for important databases and other scholarly resources, which currently often exist in a largely ad hoc manner.

\section{TECHNICAL SERVICES ARE HIGH TECH}

Academic libraries continue to have significant operations focused on selecting, purchasing, cataloging, indexing, recording, and making available collections in all formats albeit increasingly digital. Large cooperative utilities emerged to enable sharing of expertise to process and gain access to scholarly resources. OCLC

21 OCLC WorldCat. http://www.worldcat.org/

22 DLF's Aquifer. http://www.diglib.org/aquifer/ 
stands out in the early $21^{\text {st }}$ century as the primary utility for this work featuring, at this writing, 96 million records and evolving into the digital age with more cooperative services including Worldcat.org and Worldcat Local. Academic libraries still base their technical services operations on integrated library systems but we are on the cusp of major change where such products as Worldcat Local have the capability of supplanting many of the functions of an integrated library system. Additionally, the propensity for users to gain access to resources, not through library catalogs, but through browsers, notably Google, will change the landscape of technical services even more as we strive to better connect users with what Lougee terms as the "diffuse" library. ${ }^{23}$ Currently, academic libraries are dependent on interlibrary loan increasingly providing desktop electronic delivery but also moving physical books from libraries to faculty and students through a variety of delivery services. Some academic libraries are pursuing a "digitize on demand" strategy when possible to delivery virtually everything in digital form but that direction is still evolving.

Scholarly journals are now largely digital, which calls into question the need to acquire and store print versions. Mass digitization of books will bring major changes to technical services operations as academic libraries strive to focus on core activities not done by other entities. The academic library's mission to preserve scholarly resources for future generations remains but in different forms. Currently two major efforts to preserve both commercial and locally digitized content exist - LOCKSS $^{24}$ and Portico. ${ }^{25}$ These systems are providing academic librarians in North America with greater confidence in digital persistence over time and are changing the need to store redundant print copies.

\section{PROFESSIONAL PREPARATION}

The majority of academic librarians in North America obtain a master's degree from an American Library Association (ALA) accredited degree program to prepare for their career. Currently 57 institutions of higher education in North America offer the accredited master's program. ${ }^{26}$ Many academic librarians also have a subject master's degree and a few have the Ph.D. in a specific field. However, an additional graduate degree, while desirable, is not typically required. Both the As-

23 Lougee, Wendy Pradt (2002). Diffuse Libraries: Emergent Roles for the Research Library in a Digital Age. Washington DC: CLIR.

${ }^{24}$ LOCKSS (Lots of Copies Keeps Stuff Safe). http://www.lockss.org/lockss/Home

25 Portico. http://www.portico.org/

26 American Library Association. Alphabetical List of ALA-Accredited Institutions. http://www.ala.org/ ala/accreditation/lisdirb/alphaaccred.cfm 
sociation for Research Libraries ${ }^{27}$ and the American Library Association ${ }^{28}$ conduct annual salary surveys to benchmark salaries for different types of academic librarians as well as for administrators. Academic libraries are increasingly hiring professionals with other types of training, especially information technologists. Other non-librarian professionals in academic libraries include human resources specialist, fundraiser, accountant, and a wide range of supervisors. Additionally, university libraries are increasingly interested in individuals with graduate degrees in specialized areas, particularly foreign languages, to take on what was once considered responsibilities for traditionally trained librarians. A select number of specialized training programs for these specialists exist in individual libraries or in a consortia of libraries.

\section{CONCLUSION}

Academic libraries in North America are experiencing unprecedented change and transformation as scholarship becomes more digital and communication more networked. These changes affect physical and virtual spaces. They affect services and relationships. They affect education, training, and career development. They affect the library's organizational structure. Change in the $21^{\text {st }}$ century is revitalizing the dynamics of the modern research library and the university in dramatic and long lasting ways. North American academic libraries will look very different by mid-century but will still persist as fundamental to faculty and student success. North Academic libraries will play an even larger role in the production and dissemination of scholarship but in a more interconnected way with international colleagues recognizing that knowledge encompasses the world.

27 Association of Research Libraries. ARL Annual Salary Survey. http://www.arl.org/stats/annualsurveys/ salary/index.shtml

28 American Library Association. Office for Research and Statistics. ALA Survey of Librarians Salaries 2006 (summary).http://www.ala.org/ala/ors/reports/2006_Salary_Survey_Final_Report.pdf 